\title{
Notes on the morphology, ecology and distribution of Quisqualis parviflora (Combretaceae)
}

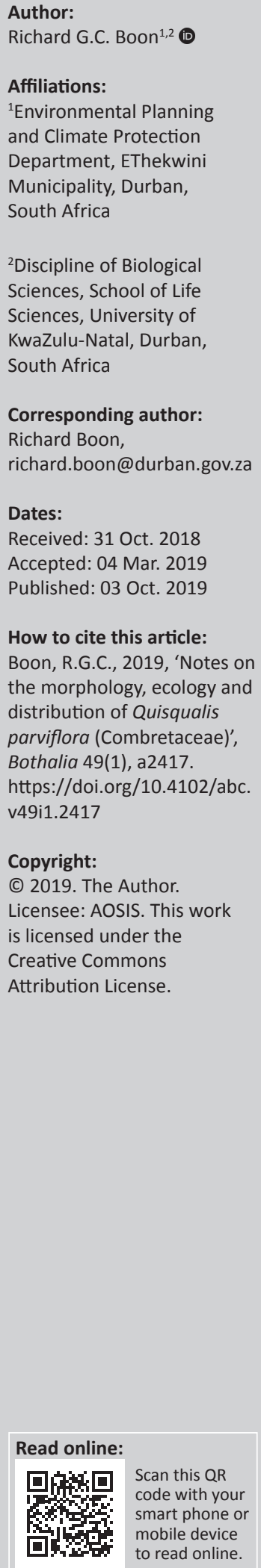

Background: Quisqualis parviflora Gerrard ex. Sond. is endemic to the KwaZulu-Natal and Eastern Cape provinces, South Africa. The species' distribution has previously been thought to extend to Mpumalanga and the KwaZulu-Natal midlands. Most published distributions include Maputaland in north-eastern KwaZulu-Natal, and it has been suggested that the species may occur in Mozambique. Sterile material of several Combretum Loefl. lianas may be confused with $Q$. parviflora.

Although the species may be locally common, it has never been collected in fruit. Published fruit descriptions are based on erroneously identified material.

Objectives: The aim of this study was to supply a revised distribution range, to describe the fruit of $Q$. parviflora and to present notes on the phenology and ecology of the species.

Method: Herbarium specimens of Q. parviflora, and similar taxa, were examined in various herbaria. Fieldwork was undertaken, and other active field botanists were consulted.

Results: Quisqualis parviflora is almost entirely restricted to scarp forest between Port St. Johns in the Eastern Cape and Eshowe in KwaZulu-Natal. Although the species may be locally common, it has only been collected from a few localities. The current dispersal ability of the species may be extremely limited, which could have long-term conservation implications.

Samaras are described, and notes are provided on the phenology and ecology of the species.

Conclusion: Although not currently threatened, the long-term prospects of Q. parviflora may be less secure. Proposed forest management interventions like liana thinning should not be undertaken without more information.

Keywords: Quisqualis parviflora; Combretum sylvicola; fruit; distribution; phenology; ecology; lianas; forest.

\section{Introduction}

Quisqualis parviflora Gerrard ex. Sond. (Combretaceae) is the sole South African member of the genus Quisqualis L., a genus which includes 12 species (The Plant List 2013). However, if the alternative classification that includes Quisqualis in a broadly defined Combretum Loefl. is adopted, the species is known as Combretum sylvicola O. Maurin (IPNI 2019; Jordaan et al. 2011).

This robust forest liana is a South African endemic and is found in the provinces of the Eastern Cape and KwaZulu-Natal (Jordaan 2006; Jordaan et al. 2011). It was previously thought to occur in Mpumalanga (Bredenkamp 2000; Carr 1986; Van der Schijff \& Schoonraad 1971), but plants from there attributed to Q. parviflora have since been identified as Combretum edwardsii Exell (McCleland 2002). The species' range has also been considered to include the KwaZulu-Natal midlands (Pooley 1993), but Jordaan et al. (2011:167) contend that these records are of C. edwardsii, 'and/or probably an undescribed species of Combretum'. Jordaan et al. (2011) omit Mpumalanga and KwaZulu-Natal midlands localities and describe the habitat and range of Q. parviflora as coastal forest from Ndumu Game Reserve in far northern KwaZulu-Natal (Maputaland) to Port St. Johns in the Eastern Cape. Carr (1986) also included Maputaland in his range for the species and speculated that it may occur in southern Mozambique, but Schmidt (2018) records no Quisqualis species in that country.

Carr (1986) states that Q. parviflora has five-winged samaras, but Jordaan et al. (2011) were unable to find any fruiting material of this species in South African herbaria and suggested that Carr may have based his description on generic descriptions taken from non-African material. Furthermore, the fruit illustrated in Carr (1986) was collected at Mariepskop (Van der Schijff 6043 in PRU) in 
Mpumalanga, but, as previously stated, this specimen has since been identified as C. edwardsii. It is quite remarkable that a locally common and prominent plant like Q. parviflora, first collected in the early 1860s at Umdloti near Durban, by W.T. Gerrard (Gerrard 24 in TCD, K), has seemingly never been collected in fruit. According to Carr (1988), the wellknown botanist H.B. Nicholson only saw flower and fruit after 17 years of weekly field excursions in southern KwaZulu-Natal; although if any herbarium specimens of fruiting material were collected by him, their whereabouts are unknown. Other active field botanists, for example Tony Abbott at the Umtamvuna Nature Reserve (Jordaan et al. 2011), G. Grieve, G. Nichols and D. Styles (all pers. comm.) and the author (until recently), have not encountered fruit in the field, further confirming its apparent rarity. Jordaan et al. (2011) hinted that the paucity of flowering (and by implication fruiting) material for $Q$. parviflora in herbaria may be because the flowers are inconspicuous and borne in the canopy of tall forest trees well out of the reach of plant collectors. Hence, they highlighted the need for more field observations on the flowering and reproductive behaviour of the species.

This note aims to present the first irrefutable description of the fruit of $Q$. parviflora, to refine the most recent published habitat and distribution descriptions and to suggest that it may be one of a number of local liana species apparently increasing in abundance and biomass as recorded elsewhere in a number of studies in Neotropical forests (Schnitzer \& Bongers 2011).

\section{Methods}

Herbarium specimens of Q. parviflora, as well as taxa with which it could have been confused, were examined in the KwaZulu-Natal Herbarium (NH), the Bews Herbarium (NU), the Ward Herbarium (UDW), the Hugh Nicholson and Tony Abbott Herbarium (PCE) and the National Herbarium, Pretoria (PRE). Herbarium codes follow Index Herbariorum (Thiers continuously updated). Quisqualis parviflora specimens are listed geographically in the section 'Specimens examined' by degree and quarter degree and then in date order (oldest to newest). Specimens seen on the Aluka Library website, http://www. jstor.org/, are distinguished by the code e!. The specimen from Mariepskop (Van der Schijff 6043 in PRU) that was illustrated in Carr (1986), and originally identified as Q. parviflora, was examined by A.E. van Wyk at PRU. In addition, the author made two collections of fruiting material under KwaZuluNatal Wildlife permit number OP 833/2018, and has made anecdotal observations of and photographed this species on a number of occasions over the last 20 years. Other field botanists were also consulted in preparing this note.

\section{Ethical considerations}

This article followed all ethical standards for research without direct contact with human or animal subjects.

\section{Results \\ Distribution and habitat}

At times herbarium collections of $Q$. parviflora have been confused with C. edwardsii, Combretum bracteosum (Hochst.)
Engl. \& Diels and an undescribed species of Combretum from Maputaland in north-eastern KwaZulu-Natal (Boon 2010). These species are, like Q. parviflora, woody lianas or scandent, multi-stemmed shrubs. Erroneous identifications are not unexpected given that sterile, dried specimens of all these taxa are similar. However, herbarium or field identifications of sterile specimens can be confirmed, for example, by observing the dense, short, reddish-brown hairs on the twigs and leaves and red-brown scales (visible with a $10 \times$ lens) on the abaxial leaf surfaces of C. edwardsii; the grey branchlets, glutinous leaves and samaras, scales invisible with a $10 \times$ lens, lack of long hairs and modified petiole bases of the undescribed Maputaland Combretum; and the often distinctly apiculate leaves lacking scales, shorter and sparser indumentum, pale twigs and some petiole bases modified as recurved hooks in C. bracteosum. In contrast, $Q$. parviflora lacks scales, has minute whitish, clear glands just discernible with a $10 \times$ lens, relatively sparse, longish hairs on leaves and new growth, recurved petiole bases modified for climbing and the young woody parts are redbrown. Combretum edwardsii has dimorphic leaves (Maurin et al. 2011), and leaves at the base of the plant, for example those on coppice shoots, can be superficially very similar to that of Q. parviflora, but the latter lacks the leaf scales of the former. A number of sterile herbarium specimens have been incorrectly identified: Strey 9839 (in NH and PRE) is C. bracteosum, Moll 2958 (in NU and PRE) is C. edwardsii and Gerstner 4552 and 4963 and De Moor 35 (all in PRE) are Combretum sp. nov.

Thus, reference to correctly identified specimens and field experience shows the actual range of $Q$. parviflora to be from Port St. Johns (Eastern Cape) in the south to Eshowe and the Ongoye Forest Reserve in KwaZulu-Natal to the north (Figure 1). No flowering or fruiting specimens were seen from outside this range and no specimens come from Mistbelt Forest or Maputaland. All but two collections have been taken from scarp forest from near sea level in the Eastern Cape to $600 \mathrm{~m}$ above sea level at the Dlinza Forest, Eshowe. One collection (C.J. Ward 5313 in NH, NU, PRE, UDW) was gathered in forest on a steep, south-facing, rocky slope at Jeffels Hill, Isipingo, south of Durban, where the approximate elevation is

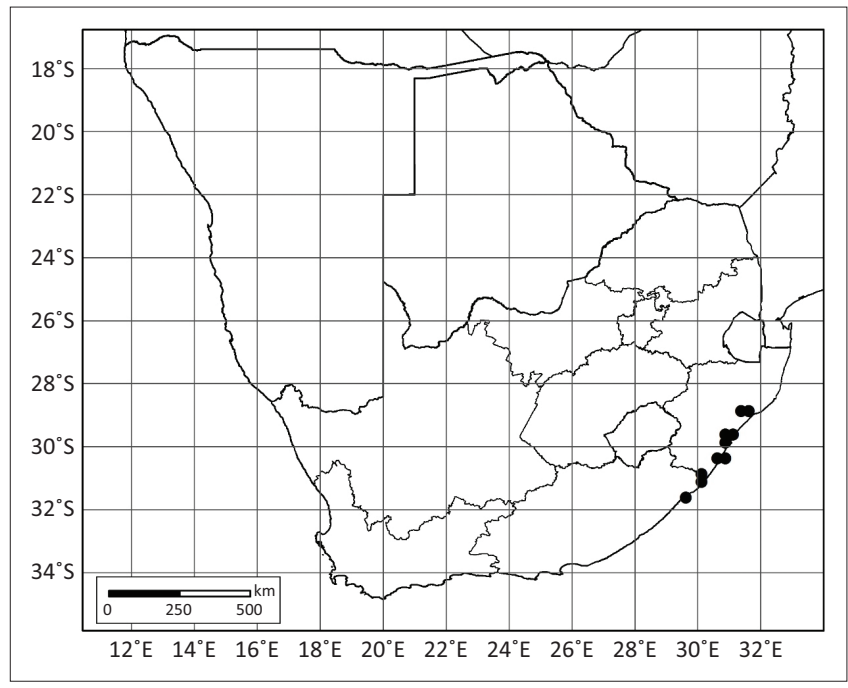

Source: Courtesy of Hester Steyn, South African National Biodiversity Institute FIGURE 1: Distribution of Quisqualis parviflora. 
$50 \mathrm{~m}$ above sea level. Unfortunately, the forest at this site is now rather degraded and it is unsafe to visit. Another specimen (M.J. McKen 41 in NH) was collected at Umdloti, Durban, where the elevation is again approximately $50 \mathrm{~m}$ above sea level. This may also be the locality of the type specimen, but there is insufficient information available to confirm this.

It is noteworthy to reflect that although $Q$. parviflora may be locally common, it has only been collected at about a dozen forests or forest complexes (see section 'Specimens examined'). At Durban, the species seems to be essentially confined to old scarp forest, almost always in association with gorges and scree slopes. Quisqualis parviflora also seems to be absent from apparently suitable scarp forest sites at Durban, for example Giba Gorge (Winston Park/St. Helier) and Tanglewood Nature Reserves (Kloof/Motala Farm). Eeley et al. (1999) modelled forest distribution in KwaZulu-Natal in response to climate change and concluded that areas currently occupied by scarp forest may well have acted as refugia for more temperate Afromontane forest during the last glacial maximum (ca. $18000 \mathrm{BP}$ ). The modern pattern of occurrence and habitat preference of $Q$. parviflora and its very limited ability to reproduce sexually and disperse to new sites suggest that the species may have been reduced to scarp forest climate refugia by the last glacial maximum. Given how few fruits it produces, it has presumably subsequently been unable to spread from disjunct scarp forest sites in the warmer, wetter climate of the Holocene. This may have future conservation implications for a species currently listed as Least Concern in the Red List of South African Plants (Foden \& Potter 2005).

\section{Fruit}

On 06 May 2018, five samaras were found between $3.5 \mathrm{~m}$ and $8.0 \mathrm{~m}$ from the ground on a plant of $Q$. parviflora growing in the Krantzkloof Nature Reserve(KNR), Durban (29 $45^{\prime} 55.08^{\prime \prime} \mathrm{S}$ $30^{\circ} 50^{\prime} 1.69^{\prime \prime} \mathrm{E}$ ). Two specimens were collected (Boon 128 and Boon 131, both in NH). All samaras were five-winged and one mature fruit measured $25 \mathrm{~mm} \times 20 \mathrm{~mm}$ (Figure 2). This fruit was oblong-elliptic, pale golden-brown on the wings and darker around the seedpod. A specimen with two slightly immature samaras was collected on 31 May 2018. These bright, lime-green fruit seemed to be damaged by insects and measured $25 \mathrm{~mm} \times 15 \mathrm{~mm}$ and $23 \mathrm{~mm} \times 15 \mathrm{~mm}$ (Figure 3) Fruit seems to develop rapidly after flowering.

\section{Phenology}

Based on 19 flowering specimens and photograph dates, peak flowering time is March to May with one specimen flowering as early as February. This flowering period agrees with that supplied by Carr (1986). Two flowering specimens collected in November and December may represent unseasonal flowering, although a specimen originally from the Umtamvuna Nature Reserve in southern KwaZulu-Natal, grown in Johannesburg, flowered consistently in September (Carr 1986).

\section{Ecology}

Anecdotal observations (P. Candotti, C. Smart and B. von Dongen pers. comm.), based on the area of tree canopy covered by robust climbers at the KNR and surrounds, suggest that the relative abundance of lianas is increasing. These observations accord with findings in a number of studies in the neotropics, but not with tropical African studies in Gabon and the Democratic Republic of Congo (Schnitzer \& Bongers 2011). According to these authors, lianas compete

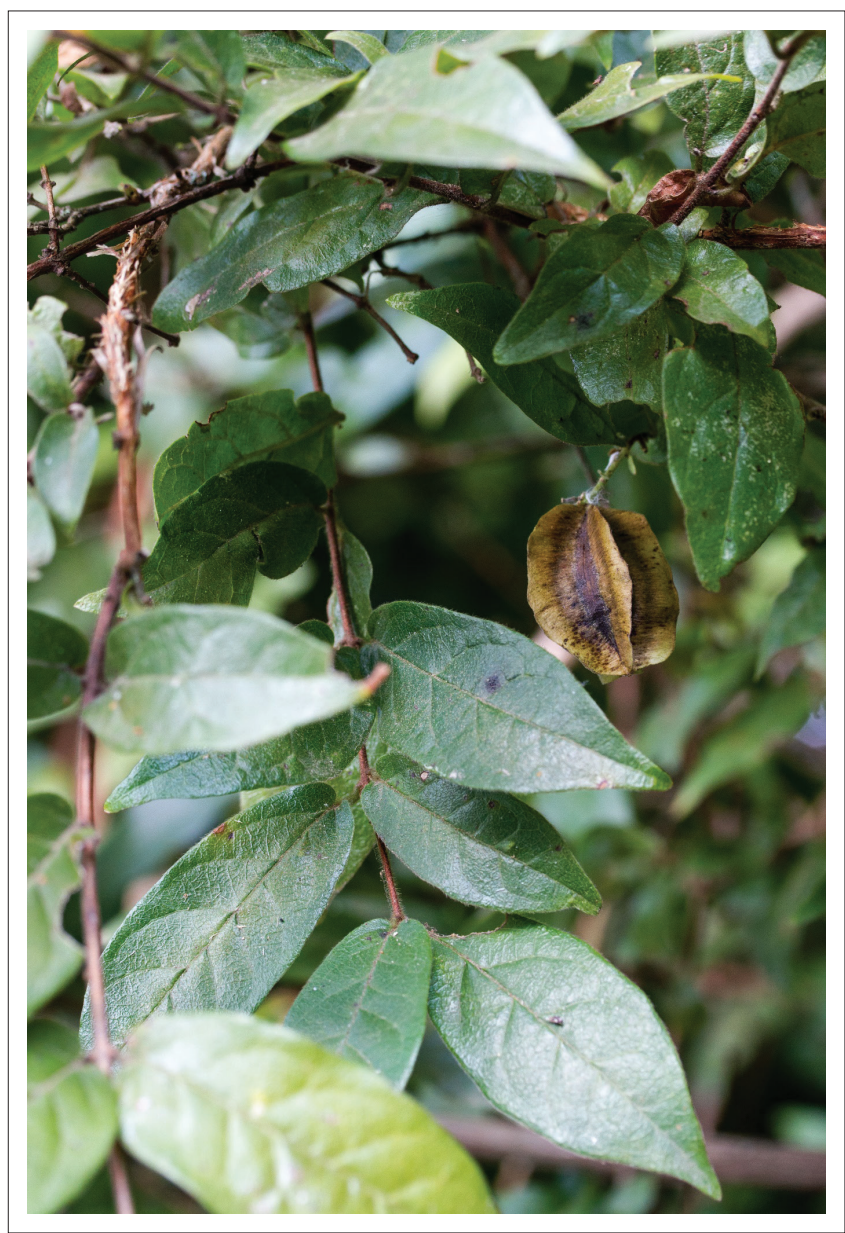

Source: Photo courtesy of R.G.C. Boon

FIGURE 2: Quisqualis parviflora mature fruit (measurement across wings ca. $20 \mathrm{~mm})$.

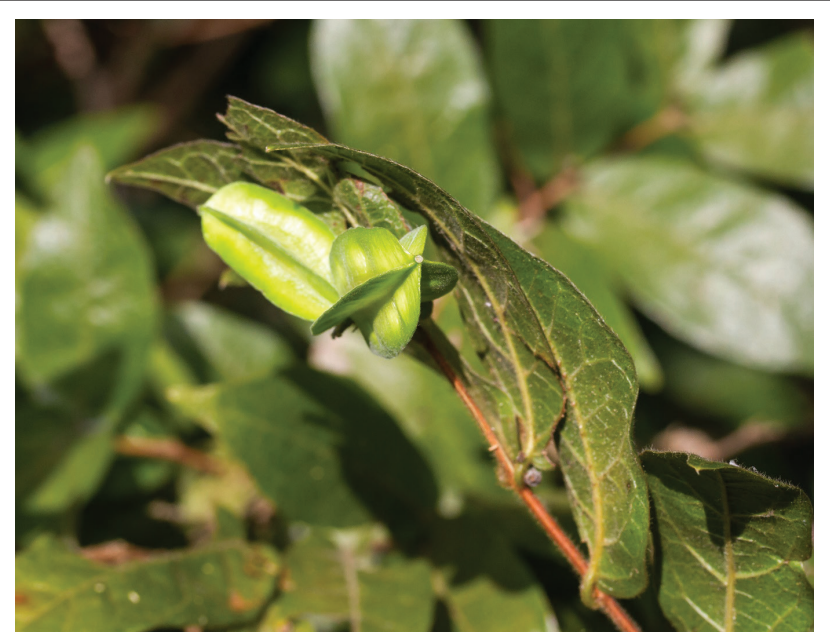

Source: Photo courtesy of R.G.C. Boon

FIGURE 3: Quisqualis parviflora immature fruit (measurement across wings ca. $15 \mathrm{~mm})$. 


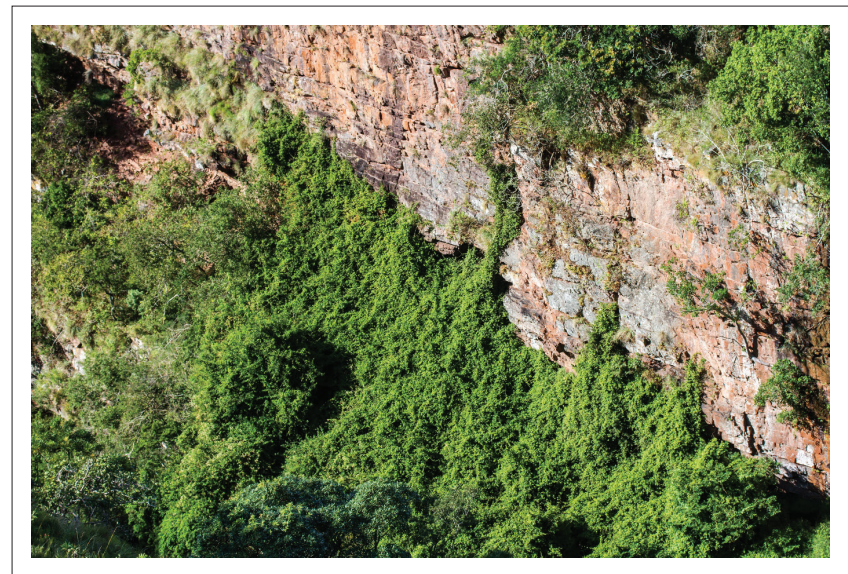

Source: Photo courtesy of R.G.C. Boon

FIGURE 4: Quisqualis parviflora (yellowish-green growth) on scarp forest canopy and Natal Group sandstone cliff, Krantzkloof Nature Reserve, Durban.

with trees and affect tree diversity and community composition, recruitment, growth and survival and carbon storage, as well as carbon, nutrient and water fluxes in forests. Reasons for increasing liana abundance and biomass are not clear yet, but seem to involve disturbance, fragmentation, elevated atmospheric $\mathrm{CO}_{2}$ levels and climate change (Schnitzer \& Bongers 2011). In the scarp forest at KNR, Q. parviflora, Oncinotis tenuiloba Stapf and Adenopodia spicata (E.Mey.) C.Presl seem to be the most abundant lianas (pers. obs.) and in places large areas of tree canopy are obscured by these plants (Figure 4). This has led to suggestions that lianas should be thinned in the protected area and in two cases outside the nature reserve landowners have killed or plan to kill lianas to protect trees. However, given the ecological importance of lianas, more studies are needed to identify the factor(s) responsible for the claimed increase of lianas in forests on Durban's scarp before resorting to such drastic action as their removal or killing. If it can be confirmed that lianas are indeed increasing, then it is most likely a symptom and should not be treated without understanding the underlying causes.

\section{Conclusion}

Quisqualis parviflora is essentially a scarp forest species currently known from about 12 forests or forest complexes. The fruit is a five-winged samara, but plants apparently only rarely reproduce sexually, if at all. This implies that it has no, or at least very limited, ability to disperse. Although Q. parviflora is currently well protected and not threatened, its long-term prospects may be less secure and proponents of liana thinning in indigenous forests should bear this in mind.

\section{Specimens examined}

KwaZulu-Natal. - 2831 (Nkandla): Eshowe Forest [Dlinza], (-CD), 20-Apr.-1939, Dr J. Gerstner 3263, (NH); Mpusheni Falls, Eshowe, (-CD), 15-May-1949, J.G. Lawn 629, (NH); Eshowe, Memorial Hill, (-CD), 15-May-1951, J.G. Lawn 1974, (NH; PRE); Zululand, Ngoye [Ongoye], (-DC), Mar.-1907, J. Wylie \& J.M. Wood 10608, (NH); Mtunzini District, Ngoya [Ongoye], (-DC), 17-Feb.-1961, Wells \& Edwards 22
(NU; PRE); Mtunzini District, left hand branch of Ngoya [Ongoye] Forest Road, (-DC), 20-Feb.-1961, Wells \& Edwards 97 (NU); Ngoye [Ongoye] Forest Reserve, (-DC), 19-Nov.1993, R. Williams 1106 (NH, PRE); 2931 (Stanger): Umhloti [Umdloti], (-CA), n.d., W.T. Gerrard 24 (TCD, holo. e!; K, iso. e!); Stonehenge, Umhloti [Umdloti], (-CA), Apr.-1862, M.J. McKen 41, (NH); 2930 (Pietermaritzburg): Inanda District, Inanda, (-DB), 04-Apr.-1948, C.G. Dosi 66 (NU); Durban, Inanda Mission Reserve 4579, Matabetulu Area, Mzinyathi Gorge, near falls, (-DB), 13-July-1993, C.J. Ward 12311, (NH, NU, UDW); Inanda District, 5 miles west of Verulam, (-DB), 15-Sept.-1965, E.J. Moll 2083 (NU, PRE); Isipingo, Jeffels Hill South, (-DD), 16-Feb.-1966, C.J. Ward 5313, (NH, NU, PRE, UDW); Krantzkloof Nature Reserve, (-DD), 24-May-1995, G. Nichols \& R. Boon 1388, (NH); Krantzkloof Nature Reserve, inland of Durban, off Bridle Road, (-DD), 11-Mar.-2005, D. Styles 2564 (NH); Krantzkloof Nature Reserve, Kloof, 2945'55.08'S 3050'1.69"E, (-DD), 10-May-2018, R. Boon 128 (NH); Krantzkloof Nature Reserve, Kloof, 2945'55.08"S 3050'1.69"E, (-DD), 31-May-2018, R. Boon 131 (NH); 3030 (Port Shepstone): Ifafa, (-BC/BD), Oct.-1945, J.G. Haycroft (NH); Vernon Crookes Nature Reserve, forest on west-facing slope in valley, (-BC), 15-Mar.1986, C.J. Ward 9831 (NH, PRE, UDW); Roessler's Farm, Tigerhole, in forest along river, (-CC), 08-Aug.-1965, R.G. Strey 5927 (NH, NU, PRE, UDW); Umtamvuna Nature Reserve, 4 km upstream, (-CC), 26-Feb.-1983, K. Balkwill $\mathcal{E}$ J. Manning 383 (NU); 3130 (Port Edward): Balulu [Bulolo] River, Umtamvuna Nature Reserve, Port Edward district, (-AA), 09-Apr.-1981, H.B. Nicholson 2171 (PRE); Umtamvuna Nature Reserve, (-AA), 16-July-1982, A. Abbott 91 (PCE); originally from the Umtamvuna River [Umtamvuna Nature Reserve], cultivated at Sandton by S.D. Carr, (-AA), Sept.-1983, J.D. Carr s.n. (PRE); Umtamvuna Nature Reserve, Bulolo, (-AA), 03-Mar.-1984, A. Abbott 1800 (NH); Umtamvuna Nature Reserve, Bulolo riverine forest, (-AA), 13-Oct.-1985, A. Abbott 2764 (PCE); Umtamvuna Nature Reserve, Fish Eagle Trail, 27-Apr.-1986, (-AA), A. Abbott 3104 (NH, PCE); Umtamvuna Nature Reserve, Umgungumbane Trail, (-AA), 14-Dec.-2006, A.T.D. Abbott 8577 (PCE).

Eastern Cape. - 3129 (Port St. Johns): Pondoland, Port St. Johns, (-DA), n.d., Dr Schonland 4219 (NU); Lotana Forest, near Ntafufu, (-DA), 11-Apr.-1991, K.H. Cooper 283 (NH, PRE); Port St. Johns, on road to Agate Terrace, (-DA), 10-Mar.-2001, P.M. Gavhi, P.J.H. Hurter E E. van Wyk 39 (PRE).

\section{Acknowledgements}

The author would like to thank Braam van Wyk for his valuable comments on this article, insights regarding the type specimens and for checking specimens in the H.G.W.J. Schweickerdt Herbarium (UPU); Hester Steyn for producing the distribution map; Hugh Glen for botanical advice; Bill Nortje for assistance and encouragement in the field; the curators and staff of the NH, NU, PCE, PRE and UDW herbaria for access to herbarium specimens; Waldo Bekker for permission to collect at the Krantzkloof Nature Reserve; and Graham Grieve, Geoff Nichols and David Styles for sharing field observations. 


\section{Competing interests}

The author declares that he has no financial or personal relationships that may have inappropriately influenced him in writing this article.

\section{Authors' contributions}

I declare that I am the sole author of this research article.

\section{Funding}

This research received no specific grant from any funding agency in the public, commercial or not-for-profit sectors.

\section{Data availability statement}

Data sharing is not applicable to this article as no new data were created or analysed in this study.

\section{Disclaimer}

The views expressed in this article are the author's own and do not necessarily reflect the official policy or position of any affiliated institutions of the author.

\section{References}

Boon, R., 2010, Pooley's trees of eastern South Africa: A complete guide, Flora \& Fauna Publications Trust, Durban.
Bredenkamp, C.L., 2000, 'Combretaceae', in O.A. Leistner (ed.), Seed plants of southern Africa: Families and genera, Strelitzia, vol. 10, pp. 228-229, National Botanical Institute, Pretoria.

Carr, J.D., 1986, 'Quisqualis parviflora', Flowering Plants of Africa 49, t. 1925.

Carr, J.D., 1988, Combretaceae in Southern Africa, Tree Society of Southern Africa, Johannesburg.

Eeley, H.A.C., Lawes, M.J. \& Piper, S.E., 1999, 'The influence of climate change on the distribution of indigenous forest in KwaZulu-Natal, South Africa', Journal of Biogeography 26, 595-617. https://doi.org/10.1046/j.1365-2699.1999.00307.x

Foden, W. \& Potter, L., 2005, 'Quisqualis parviflora Gerrard ex Sond., National Assessment: Red List of South African Plants version 2017.1, viewed 29 October 2018, from http://redlist.sanbi.org/species.php?species=2038-1.

IPNI, 2019, International Plant Names Index, viewed 01 March 2019, from http:// www.ipni.org, The Royal Botanical Gardens, Kew, Harvard University Herbaria \& Libraries and Australian National Botanical Gardens.

Jordaan, M., 2006, 'Combretaceae', in G. Germishuizen, N.L. Meyer, Y. Steenkamp \& M. Keith (eds.), A checklist of South African plants, Southern African Botanical Diversity Network Report No. 41, pp. 329, 330, SABONET, Pretoria.

Jordaan, M., Van Wyk, A.E. \& Maurin, O., 2011, 'Generic status of Quisqualis (Combretaceae) with notes on the taxonomy and distribution of $Q$. parviflora', Bothalia 41(1), 161-169. https://doi.org/10.4102/abc.v41i1.37

McCleland, W., 2002, 'Combretaceae', in E. Schmidt, M. Lötter \& W. McCleland (eds.), Trees and shrubs of Mpumalanga and Kruger National Park, p. 460, Jacana, Johannesburg.

Pooley, E., 1993, The complete field guide to trees of Natal, Zululand and Transkei, Natal Flora Publications Trust, Durban.

Maurin, O., Van Wyk, A.E., Jordaan, M. \& Van Der Bank, M., 2011, 'A new species of Combretum section Ciliatipetala (Combretaceae) from southern Africa, with a key to regional members of the section', SA. Journal of Bot 77, 105-111. https://doi. org/10.1016/j.sajb.2010.06.003

Schmidt, E., 2018, 'Combretaceae', in J.E. Burrows, S.M. Burrows, M.C. Lötter \& E. Schmidt (eds.), Trees and shrubs Mozambique, Publishing Print Matters (Pty) Ltd, Noordhoek, Cape Town.

Schnitzer, S.A. \& Bongers, F., 2011, 'Increasing liana abundance and biomass in tropical forests: Emerging patterns and putative mechanisms', Ecology Letters 14 397-406. https://doi.org/10.1111/j.1461-0248.2011.01590.x

The Plant List, 2013, Version 1.1, viewed 1 January 2018, from http://www.theplantlist.org/.

Thiers, B., continuously updated, Index Herbariorum: A global directory of public herbaria and associated staff, Botanical Garden's Virtual Herbarium, New York, viewed 08 October 2018, from http://sweetgum.nybg.org/science/ih/.

Van der Schijff, H.P. \& Schoonraad, E., 1971, 'The flora of the Mariepskop complex', Bothalia 10, 461-500. https://doi.org/10.4102/abc.v10i3.1554 